\title{
The composition of polyunsaturated fatty acids in mare's blood and foal's blood plasma at birth and the first days after parturition
}

\author{
O. Taugbøl' and M. Koene ${ }^{2}$ \\ ${ }^{1}$ Department of Biochemistry, Physiology and Nutrition, Norwegian College of Veterinary Medicine, Oslo, Norway \\ 2Tierklinik Mühlen, Germany
}

\begin{abstract}
Summary
Eight mares and their foals were included in this study. Samples of blood plasma and mare milk were obtained before the first milk intake (day 0 ) and on day 1,2 and 10 after parturition. The fatty acid composition of the total lipid fraction of plasma and milk was analyzed by gas chromatography. Immediatly after birth the concentration of linoleic acid (18:2n-6; LA) of foal blood plasma was very low compared to mare blood plasma. There was an increase in LA of foal blood plasma during the sampling period. This was probably due to the high content of $L A$ in mare milk (20-25\% of total fatty acids). In contrast to LA, dihomogammalinolenic acid (20:3n-6; DGLA) and arachidonic acid (20:4n-6; AA) were markedly higher in plasma from newborn foals than in mare plasma. The content of DGLA and AA in foal plasma decreased during the sampling period.
\end{abstract}

Keywords: $\quad$ fatty acids, delivery, blood plasma lipids, milk

\begin{abstract}
Zusammensetzung mehrfach ungesättigter Fettsäuren im Blut von Stuten und Fohlen bei der Geburt und postnatal
An dieser Untersuchung waren acht Warmblutstuten mit ihren Fohlen beteiligt. Blutplasma- und Stutenmilchproben wurden vor der ersten Kolostralmilchaufnahme (Tag 0), sowie an den Tagen 1, 2 und 10 post partum entnommen. Die Fettsäurenzusammensetzung der Gesamtlipidfraktion des Plasmas und der Milch wurde durch eine gaschromatographische Untersuchung ermittelt. Unmittelbar nach der Geburt war der Linolsäuregehalt (18:2n-6; LA) im Fohlenblutplasma verglichen zur Stute sehr niedrig. Während der Probenentnahmeperiode kam es zu einem Anstieg der LA im Fohlenplasma. Dies ist wahrscheinlich auf den hohen LA-Gehalt (20-25\% der gesamten Fettsäuren) in der Stutenmilch zurückzuführen. Die Dihomogammalinolensäure- (20:3n-6; DGLA) sowie die Arachidonsäurewerte (20:4n-6; AA) sind, anders als die LA, signifikant höher im Plasma frisch geborener Fohlen als im Stutenblutplasma. AA und DGLA im Fohlenplasma nahmen während des Untersuchungszeitraumes ab.
\end{abstract}

Schlüsselwörter: Fettsäure, Geburt, Plasmafette, Milch

Introduction

Polyunsaturated fatty acids are required during foetal development for the synthesis of eicosanoids and for the formation of membrane structures in all tissues. Evidence is growing that special long-chain polyunsaturated fatty acids are essential for normal development of brain and retina (Crawford et al. 1989; Hoffman et al. 1993).

The composition of polyunsaturated fatty acids in plasma lipids in neonates differs from the fatty acid composition in the maternal plasma in humans (Hull 1979) and in horses (Stammers et al. 1991). In the neonates the content of long-chain polyunsaturated fatty acids is higher, whereas the concentration of linoleic acid (18:2n-6; LA) is lower compared to maternal plasma. During the first days of life the fatty acid composition in blood plasma of human neonates (Hull 1979; Pita et al.,1990) and piglets (Innis et al. 1989) changes rapidly. LA rises, whereas arachidonic acid (20:4n-6; AA) and other long-chain polyunsaturated fatty acids decrease. These changes are modulated by the type of diet and postnatal age (Hull 1979).
The aim of this experiment was to study the composition of polyunsaturated fatty acids in mare and foal blood plasma at birth and the first days after parturition.

\section{Material and methods}

Eight german warmbloodmares, oldenburg brand, aged between 3 and 10 years, and their foals were included in this study. All mares were housed for at least 6 weeks prior to delivery. They were fed hay and cornsilage, oats and vitaminized pellets at their needs. Water was supplied ad libitum. Blood plasma was taken from the jugular vein and collected into heparin vacuum tubes. Milk samples were obtained by handmilking. Samples of blood plasma and mare milk were collected before the first milk intake (at birth) and on day 1,2 and 10 after parturition. The samples were stored in small plastic tubes at $-20^{\circ} \mathrm{C}$ on the farm, and at $-80^{\circ} \mathrm{C}$ in the laboratory until processed. 


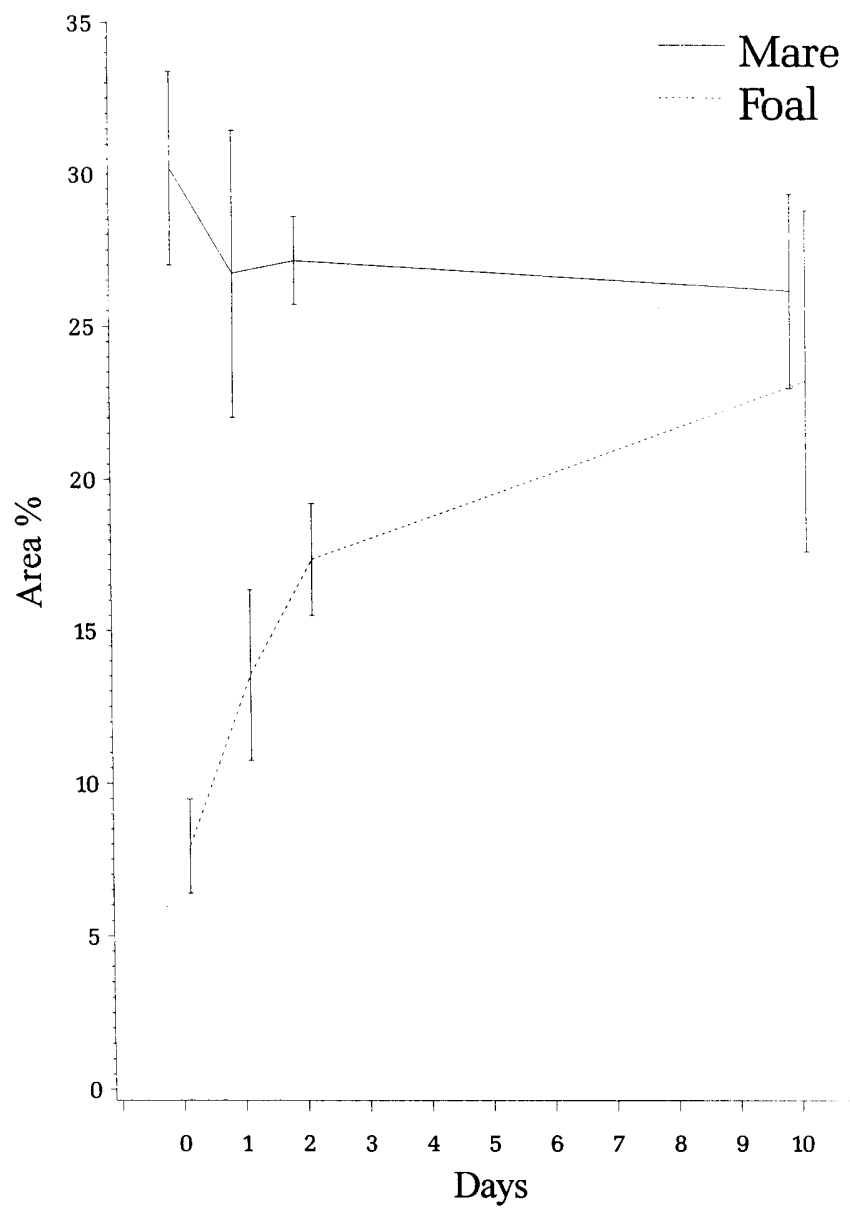

Fig. 1: The composition (area \%) of linoleic acid (18:2n-6; LA) in mare's blood and foal's blood plasma at birth and the first days after parturition. The bars indicate 2SEM.

Anteil (\%) der Linolsäure (18:2n-6; LA) im Blut der Stuten und Blutplasma der Fohlen zur Geburt und in den ersten Tagen p.p. (Balken: 2s)

Tab. 1: The fatty acid composition (area \%) of the total lipid fraction of foal blood plasma. Mean (SD).

Fettsäurenzusammensetzung in \% des Gesamtfettes im Blutplasma von Fohlen. $x(s)$

\begin{tabular}{|c|c|c|c|c|c|}
\hline Fatty acid & $\begin{array}{l}\text { At birth } \\
\text { (Day 0) }\end{array}$ & Day 1 & Day 2 & \multicolumn{2}{|c|}{ Day 10} \\
\hline $12: 0^{b}+$ & $41.9(8.5)$ & $31.3(6.2)$ & $32.1(4.5)$ & 32.5 & $(9.1)$ \\
\hline $14: 0$ & $1.12(0.67)$ & $1.13(0.59)$ & $1.02(0.43)$ & 0.80 & $(0.41)$ \\
\hline $16: 0^{a}$ & $11.1(2.0)$ & $15.0(1.6)$ & $14.5(1.3)$ & 13.6 & (2.0) \\
\hline 16:1n-7a 到 & $2.3 \quad(0.6)$ & $2.9 \quad(0.4)$ & $2.6 \quad(0.3)$ & 1.8 & $(0.7)$ \\
\hline 18:0 & $9.3 \quad(2.3)$ & $10.1(0.9)$ & $9.2 \quad(1.2)$ & 9.8 & (2.3) \\
\hline 18:1n-9a & $17.0(3.9)$ & $18.7(2.9)$ & 16.1 & 12.2 & $(4.8)$ \\
\hline $18: 2 \mathrm{n}-6^{\mathrm{b} \star}$ & $7.9 \quad(2.1)$ & $13.6(3.7)$ & $17.4(2.5)$ & 23.2 & (7.4) \\
\hline $20: 3 n-6^{a} \dagger$ & $2.01 \quad(0.80$ & $1.89(0.73)$ & $1.03(0.38)$ & 0.96 & $(0.57)$ \\
\hline $20: 4 n-6^{a} \dagger$ & $1.75(0.92)$ & $1.76(0.79)$ & $1.03(0.52)$ & 0.97 & (0.53) \\
\hline
\end{tabular}

a Foal > Mare; ${ }^{b}$ Foal < Mare; ${ }^{*}$ Increase during the sampling time.

The lipids from $0.5 \mathrm{ml}$ plasma and milk were extracted by a modification of the procedures of Folch et al. (1957),

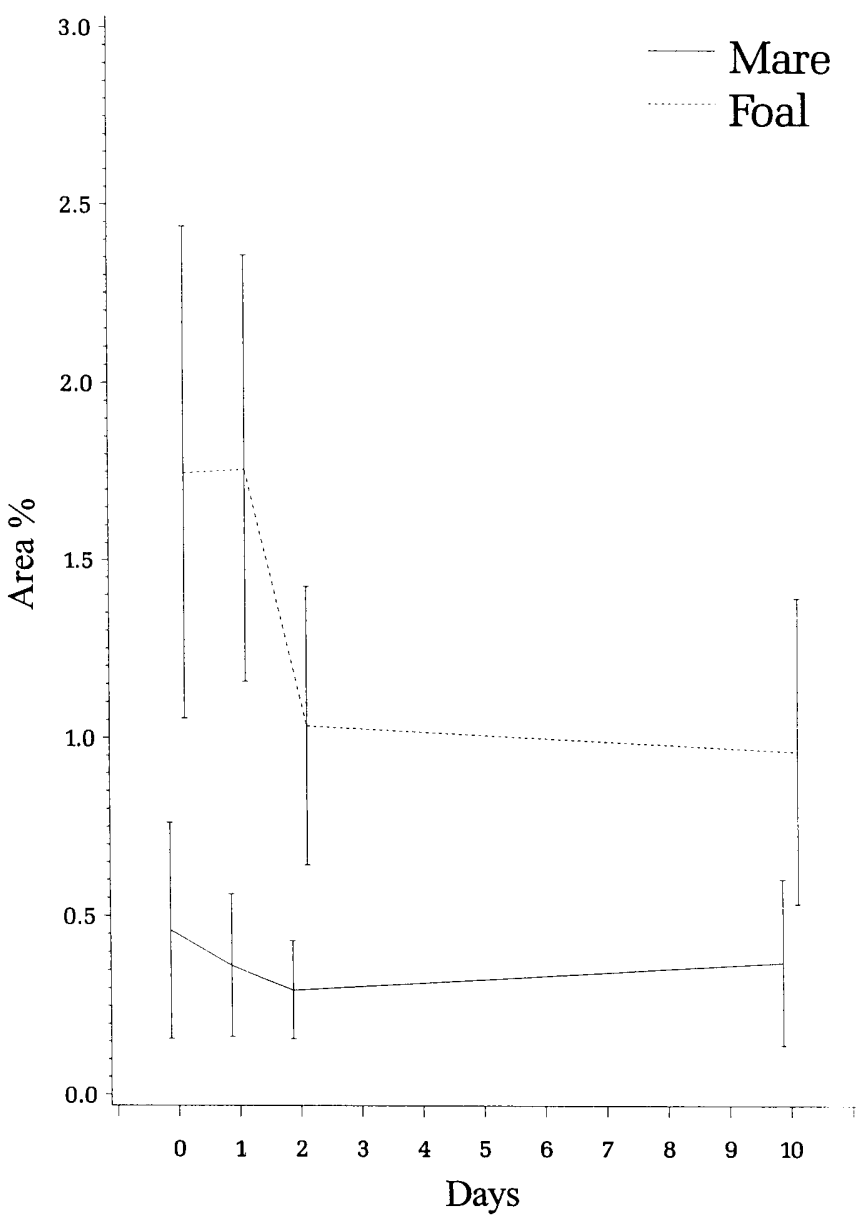

Fig. 2: The composition (area \%) of arachidonic acid (20:4n-6; AA) in mare's blood and foal's blood plasma at birth and the first days after parturition. The bars indicate 2SEM.

Anteil (\%) der Arachidonsäure (20:4n-6; AA) im Blut der Stuten und Blutplasma der Fohlen zur Geburt und in den ersten Tagen p.p. (Balken: 2s)

and methylated as described by Taugbol (1993). The methylated fatty acids were extracted with $1 \mathrm{ml}$ hexane and separated on a fused silica wall coated capillary column (Chrompack, WCOT Fused Silica (CP-Sil-5 CB); 50 $\mathrm{m} 0.25 \mathrm{~mm}$, film thickness $0.12 \mathrm{~mm}$ ) in a Dani 86.10 gas chromatograph fitted with a flame-ionization detector and a programmable temperature vaporizer (PTV) injector. Carrier gas used was helium. The injector and detector temperature was $260^{\circ} \mathrm{C}$. The column temperature was kept at $60^{\circ} \mathrm{C}$ for $1.2 \mathrm{~min}$, then increased to $200^{\circ} \mathrm{C}$ at a rate of $25^{\circ} \mathrm{C} / \mathrm{min}$, then up to $250^{\circ} \mathrm{C}$ at a rate of $0.8^{\circ} \mathrm{C} / \mathrm{min}$ (total time $70 \mathrm{~min}$ ). Identification of major peaks was made by comparing the retention time with those of standard fatty acid-methylesters. The results are reported as relative distribution of fatty acids from the percentage of the total area under the peaks.

All results are given as the mean and standard deviation (SD). The statistical analysis applied was an ANOVA, with two different factores to control for: Mare and foal plasma samples and the time trend within the sampling period. The model checking was carried out by the use of Jack- 
Tab. 2: The fatty acid composition (area \%) of the total lipid fraction of mare blood plasma. Mean (SD).

Fettsäurenzusammensetzung in \% des Gesamtfettes im Blutplasma von Stuten. x(s)

\begin{tabular}{|c|c|c|c|c|}
\hline Fatty acid & $\begin{array}{l}\text { At birth } \\
\text { (Day 0) }\end{array}$ & Day 1 & Day 2 & Day 10 \\
\hline $12: 0$ & $36.0(8.1)$ & $43.5(9.9)$ & $45.2(4.6)$ & $41.4(10.0)$ \\
\hline $14: 0$ & $0.98(0.15)$ & $1.10(0.31)$ & $1.06(0.48)$ & $1.09(0.37)$ \\
\hline $16: 0$ & $11.4(1.6)$ & $8.7 \quad(2.0)$ & $8.2 \quad(0.7)$ & $9.0 \quad(3.5)$ \\
\hline $16: 1 n-7$ & $1.08(0.43)$ & $0.48(0.13)$ & $0.50(0.15)$ & $0.77(0.50)$ \\
\hline $18: 0$ & $9.6 \quad(1.4)$ & $8.8 \quad(1.7)$ & $8.7 \quad(0.8)$ & $8.9 \quad(1.7)$ \\
\hline $18: 1 n-9$ & $8.0 \quad(1.0)$ & $6.1 \quad(1.5)$ & $5.0 \quad(0.3)$ & $5.8 \quad(1.7)$ \\
\hline $18: 2 n-6 \dagger$ & $30.2(3.6)$ & $26.7 \quad(5.8)$ & $27.2(1.9)$ & $26.2(4.2)$ \\
\hline $20: 3 n-6$ & - & - & -- & - \\
\hline $20: 4 n-6$ & $0.46(0.30)$ & $0.36(0.20)$ & $0.29(0.15)$ & $0.37 \quad(0.28)$ \\
\hline
\end{tabular}

† Decrease during the sampling time.

Tab. 3: The fatty acid composition (area \%) of the total lipid fraction of mare milk. Mean (SD).

Fettsäurenzusammensetzung in \% des Gesamtfettes in der Stutenmilch. $\times(\mathrm{s})$

\begin{tabular}{|c|c|c|c|c|}
\hline Fatty acid & $\begin{array}{l}\text { At birth } \\
\text { (Day 0) }\end{array}$ & Day 1 & Day 2 & Day 10 \\
\hline $8: 0$ & $0.85(0.37)$ & $1.10(0.58)$ & $2.40(1.26)$ & $1.87(0.81)$ \\
\hline $10: 0$ & $4.6 \quad(1.0)$ & $5.2 \quad(2.5)$ & $9.5 \quad(4.6)$ & $8.6 \quad(3.8)$ \\
\hline $12: 0$ & $16.3(6.3)$ & 10.9 & $14.8(5.0)$ & $15.8(4.8)$ \\
\hline $14: 0$ & $4.3 \quad(0.7)$ & $5.2 \quad(1.3)$ & $5.8 \quad(1.1)$ & $6.7 \quad(1.5)$ \\
\hline $16: 0$ & $21.3(2.9)$ & $21.9(1.4)$ & $20.3(2.3)$ & $21.4(2.3)$ \\
\hline $16: 1 n-7$ & $3.9 \quad(1.6)$ & $4.3 \quad(1.2)$ & $4.4 \quad(1.2)$ & $4.8 \quad(1.2)$ \\
\hline $18: 0$ & $1.56(0.90)$ & $1.41(0.50)$ & $1.09(0.43)$ & $1.07(0.63)$ \\
\hline $18: 1 n-9$ & $20.5(2.7)$ & $22.8(4.1)$ & $19.2(3.4)$ & 18.9 \\
\hline
\end{tabular}

knife residuals and Cook's d. The level of significance was set to 0.05 .

\section{Results}

The fatty acid compositions of foal's and mare's blood plasma are presented in table 1 and 2, respectively. Immediatly after birth the concentration of LA of foal blood plasma was very low compared to mare blood plasma. There was an increase in LA of foal blood plasma during the sampling period, fig. 1. In contrast to $L A$, dihomogammalinolenic acid (20:3n-6; DGLA) and arachidonic acid AA were markedly higher in plasma from newborn foals than in mare plasma. The content of DGLA and AA in foal plasma decreased during the sampling period. Fig. 2 shows the relative concentration of AA in foal and mare plasma lipids.

The fatty acid composition of mare milk lipids is shown in table 3. Mare milk contained about $20-25 \%$ of LA, but only minor traces of other polyunsaturated fatty acids.

\section{Discussion}

In agreement with Stammers et al. (1991) we found the percentage of LA markedly lower and of DGLA and AA markedly higher in newborn foal plasma lipids than in maternal mare plasma lipids. These differences between foetal and maternal plasma lipids are also known from humans (Hull 1979; Ruyle et al. 1990) and other mammals (Innis et al. 1989). In humans the total lipid concentration is lower in cord blood than in maternal blood at delivery (Ruyle et al. 1990), and the absolute amount of AA in umbilical plasma is therefore lower compared with maternal values (Ruyle et al. 1990; Al et al. 1995). In the horse the content of total blood lipids in foetal venous blood is almost as high as in maternal venous blood (Stammers et al. 1991). Therefore the relative composition of total plasma fatty acids reflects the absolute fatty acid status in the horse.

The occurrence of polyunsaturated $\omega 6$ fatty acids in foetal plasma demonstrates placental transfer, because they cannot be synthesized in mammalian tissues. The higher amounts of DGLA and AA could be due to de novo synthesis by the fetus and the placenta. The evidence for fetal and placental elongation and desaturation of LA is sparse and to some extent conflicting (Scott and Bazan 1989; Booth et al. 1981; Zimmermann et al. 1979; Chambaz et al. 1985). A prefered transport of DGLA and AA at the expense of LA may also be responsible (Kuhn and Crawford 1986). Long chain polyunsaturated fatty acids seem to be hidden within a lipid fraction that does not recross the placental barrier. An $\alpha$-fetoprotein is supposed to carry out this role. This protein is mainly synthesized by the fetal liver and the yolk sac. Although the biological role of $\alpha$-fetoprotein is not completely elucidated, it binds polyunsaturated fatty acids with high affinity (Subbiah 1991). Not only different fractions of plasma lipids, but also the phospholipids of erythrocytes may play a role in the necessary transport of polyunsaturated fatty acids into the fetus. Ruyle et al. (1990) found a venous-arterial difference in umbilical erythrocytes for docosahexaenoic acid (22:6n-3; DHA).

Between the first and the second day of life a dramatic decrease in the foal's plasma lipid concentration of DGLA and AA occurred. This is probably due to an expanding plasma volume as a result of higher milk intake, and a decreased dry matter content of colostrum. Immediately after foaling the dry matter content of colostrum is about $25 \%$, whereas the dry matter content on day 2 differs only slightly from those obtained 5 days after foaling, about 12\% (Csapó et al. 1995). The rapid decrease of DGLA and AA could also indicate a placental fatty acid elongation and desaturation activity, which cannot be compensated by biosynthesis of long-chain polyunsaturated fatty acids in the newborn foal.

The main dietary polyunsaturated fatty acid, LA, increased in foal blood plasma from the first milk intake.

In this study we did not find any $\omega 3$ polyunsaturated fatty acids, neither in blood plasma nor in milk. Csapó et al. (1995) found high amounts of linolenic acid (18:3n-3; LNA) in mare milk, probably due to a pasture of better quality in Hungary than we can expect in North-Germany in the early spring time. Stammers et al. (1991) did find 
long-chain $\omega 3$ fatty acids in both mare and foal blood plasma, whereas these fatty acids were under the detection limit for the analyses carried out in our experiment.

\section{Acknowledgement}

We thank Hiltrud Kremer for her help with sampling, Kari Feigenwinter and Sumithra Taraldsen, Department of Biochemistry, Physiology and Nutrition, Norwegian College of Veterinary Medicine, for their help with preparations for GC-analyses of the fatty acids in the blood plasma and milk samples. Statistical advice was given by Petter Mowinkel, Oslo, Norway.

\section{References}

Al, M. D. M., van Houwelingen, A. C., Kester, A. D. M., Hasaart, T. H. M., . Dejong, A. E. P and Hornstra, G. (1995): Maternal essential fatty acid patterns during normal pregnancy and their relationship to the neonatal essential fatty acid status. Br. J. Nutr. 74, $55-68$

Booth, C., Elphick, M. C. , Hendrickse, W. and Hull, D. (1981): Investigation of $\left[{ }^{14} \mathrm{C}\right]$ linoleic acid conversion into $\left[{ }^{14} \mathrm{C}\right]$ arachidonic acid and placental transfer of linoleic and palmitic acids across the perfused human placenta. J. Dev. Physiol. 3, 177-189

Chambaz, J., Ravel, D., Manier, M. C., Pepin, D., Mulliez, N. and Bereziat, G. (1985): Essential fatty acids interconversion in the human fetal liver. Biol. Neonate. 47, 136-140

Crawford, M. A., Doyle, W., Drury, P., Lennon, A., Costeloe, K. and Leighfield, $M$. (1989): $n-6$ and $n-3$ fatty acids during early human development. J. Internal Med. 225 (suppl. 1), 159-169

Csapó, J., Stefler, J., Martin, T. G., Makray, S. and Csapó-Kisa, Zs. (1995): Composition of mares' colostrum and milk. Fat content, fatty acid composition and vitamin content. Int. Dairy J. 5 , 393-402

Folch, J., Slees, M. and Sloane Standley, G. H. (1957): A simple method for the isolation and purification of total lipids from animal tissues. J. Biol. Chem. 226, 497-509

Hoffman, D. R., Birch, E. E., Birch, D. G. and Uauy, R. D. (1993): Effects of supplementation with $\omega 3$ long-chain polyunsaturated fatty acids on retinal and cortical development in premature infants. Am. J. Clin. Nutr. 57 (suppl), 807S-812S
Hull, D. (1979): Fatty acid metabolism before and after birth. In: Visser, H. K. A. (ed.) Nutrition and metabolism of the fetus and infant. Hague: Martinus Nijhoff Publishers b.v., 109-122

Innis, S. M., Hrboticky, N. and Foote, K. D. (1989): Essential fatty acid metabolism in infants. Nutrition 5, 256-258

Kuhn, D. C. and Crawford, M. (1986): Placental essential fatty acid transport and prostaglandin synthesis. Prog. Lipid Res. 25, 345-353

Pita, M. L., de Lucchi, C., Faus, M. J. and Gill, A. (1990): Changes in the fatty acid profiles of red blood cell membrane phospholipids in human neonates during the first month of life. Clin. Physiol. Biochem. 8, 91-100

Ruyle M., Connor, W. E., Anderson, G. J. and Lowensohn, R. I. (1990): Placental transfer of essential fatty acids in humans: Venous-arterial difference for docosahexaenoic acid in fetal umbilical erythrocytes. Proc. Natl. Acad. Sci. USA 87, 7902-7906

Scott, B. L. and Bazan, N. G. (1989): Membrane docosahexaenoate is supplied to the developing brain and retina by the liver. Proc. Natl. Acad. Sci. USA. 86, 2903-2907

Stammers, J. P., Hull, D., Leadon, D. P., Jeffcott, L. B. and Rosadale, P. D. (1991): Maternal and umbilical venous plasma lipid concentrations at delivery in the mare. Equine Vet. J. 23, 119-122

Subbiah, M. T. R. (1991): Newly recognized lipid carrier proteins in fetal life. Proc. Soc. Exp. Biol. Med. 198, 459-499

Taugbøl, O. (1993): Omega-3 fatty acid incorporation in fat and muscle tissues of growing pigs, fed supplements of fish oil. J. Vet. Med. A. 40, 93-101

Zimmermann, T., Winkler, L., Möller, U., Schubert, H. and Goetze, E. (1979): Synthesis of arachidonic acid in human placenta in vitro. Biol. Neonate. 35, 209-212

Ole Taugbol

Department of Biochemistry, Physiology and Nutrition

Norwegian College of Veterinary Medicine

P.O.Box 8146 DEP

0033 Os/o

Norway

Marc Koene

Tierklinik Mühlen

Münsterlandstr. 51

49439 Mühlen

Germany 